\title{
Correction to: MicroRNA-138-5p targets the NFIB-Snail 1 axis to inhibit colorectal cancer cell migration and chemoresistance
}

Weifeng Xu', Beibei Chen ${ }^{1}$, Dianshan $\mathrm{Ke}^{2^{*}}$ and Xiaobing Chen ${ }^{1 *}$ (D)

\section{Correction to: Cancer Cell Int (2020) 20:475}

https://doi.org/10.1186/s12935-020-01573-5

Following publication of the original article [1], we were notified that Dr. Xiaobing Chen should be marked as the first corresponding author.

The original article has been corrected.

Published online: 03 November 2020

\section{Reference}

1. Xu W, Chen B, Ke D, Chen X. MicroRNA-138-5p targets the NFIB-Snail1 axis to inhibit colorectal cancer cell migration and chemoresistance. Cancer Cell Int. 2020:20:475. https://doi.org/10.1186/s12935-020-01573-5.

\section{Publisher's Note}

Springer Nature remains neutral with regard to jurisdictional claims in published maps and institutional affiliations.

The original article can be found online at https://doi.org/10.1186/s1293 5-020-01573-5.

*Correspondence: kds8810@163.com; xiaobingchen01@163.com

${ }^{1}$ Department of Medical Oncology, The Affiliated Cancer Hospital of Zhengzhou University, 127 Dong Ming Road, Zhengzhou 450008,

Henan, People's Republic of China

${ }^{2}$ Department of Cell Biology, Southern Medical University,

Guangzhou 510515, Guangdong, China

(c) The Author(s) 2020. This article is licensed under a Creative Commons Attribution 4.0 International License, which permits use, sharing, adaptation, distribution and reproduction in any medium or format, as long as you give appropriate credit to the original author(s) and the source, provide a link to the Creative Commons licence, and indicate if changes were made The images or other third party material in this article are included in the article's Creative Commons licence, unless indicated otherwise in a credit line to the material. If material is not included in the article's Creative Commons licence and your intended use is not permitted by statutory regulation or exceeds the permitted use, you will need to obtain permission directly from the copyright holder. To view a copy of this licence, visit http://creativecommons.org/licenses/by/4.0/. The Creative Commons Public Domain Dedication waiver (http://creativecommons.org/publicdomain/zero/1.0/) applies to the data made available in this article, unless otherwise stated in a credit line to the data. 